\title{
Optimizing Smile Police By Supporting The Awareness Of The Promoter Police (Professional, Modern And Trusted)
}

\author{
Amin Fauzi,S.Kom ${ }^{\mathrm{a}}$. and Ismi Dwi Astuti Nurhaeni, Prof. Dr., M.Si. ${ }^{b}$ \\ ${ }^{a, b}$ Faculty of Social and Political Sciences, Universitas Sebelas Maret, Central Java, \\ Indonesia \\ aamin.indonesia@yahoo.com, ${ }^{\mathrm{b}}$ ismidwiastuti@staff.uns.ac.id
}

\begin{abstract}
In order to improve the quality of public service to be Promoter (Professional, Modern and Trusted), POLRI (Police of Republic of Indonesia) develops an innovation by applying Information Communication Technologies (ICT) in the form of Information Management System of Electronic Police Service (Smile Police). Smile Police is a development of an innovation of Central Java Regional Police promoting the public service and aims to improve the agility of police services. This research method uses literature study, the data collected are taken from several international journals, national journals, books and documentation. This article discusses how is the operation of both Smile Police performance and the obstacles of Smile Police. The results find that Smile Police has not been operated optimally because of the six Smile Police applications, there are only three applications that have been regularly used, namely: E-Office, Panic Button, and E-Bhabin. There are still three other applications that have not been optimally used, namely Public Service, E-learning and E-Complaint. Changing the work culture from manual system to electronic system, inadequate socialization of the Police to the public about using and accessing Smile Police, unavailability of Android-based Smartphone for Police members, lack of Police human resources understanding the information technology, and public E-literacy. Smile Police optimization can be performed by eliminating the inhibiting factor of Smile Police operation.
\end{abstract}

Keywords: Smile Police; POLRI; ICT; Quality of Public Service; Promoter

\section{Introduction}

Presently, the level of public confidence in the Police tends to decrease. The results of Poltracking survey research institute in November 2017, the level of public confidence in the Police institution was still below of several Ministries and Institutions. TNI is in the first rank with $76 \%$, President by $75 \%$, KPK by $68 \%$, General Election Commission (KPU) by 63\%, and Police by 61\% (source: news.metrotvnews.com). According to Sufianti (2007), the low quality of service occurs almost in all aspects of public services, i.e. on aspects of services, administrative services and goods service. The decreasing level of public confidence to the Police is due to the main problem that is not yet reaching the maximum performance of the Police in providing services to the public. In addition, there is a culture within the organization and individual of POLRI which is negative in the public eye. For example, they are behavioral patterns of corruption, the arrogance of authority, and excessive violence are making the doubt of public to the Police.

The development and modernization growing in society are increasing constantly also the needs of the community. In the present time, technology is the most widely 
experienced rapid development. People need technology to support daily activities and needs, including the need for information and public services. Improved public services is more convenient for the community based on Information Technology (IT) to be a way for police organizations to maximize performance and to maintain the existence of Police in providing services to the community by making creative breakthroughs and innovations in the field of Information Technology.

To create a good public service, it needs innovation. The five types of innovations by Baker and IDeA in Prasojo, et.al., (2007) include innovations related to strategy or policy (e.g. missions, targets, strategies and new considerations), service / product (e.g. features change and service design) delivery of services (e.g. changes or new ways of delivering services), processes (e.g. internal procedures, policies and new organizational forms), and interaction systems (e.g. new ways or knowledge-based improvements in interacting with other roles and changes in the way of government performed).

Central Java Police in effort to improve the quality of public services through the operation of Information Communication Technologies (ICT) is to create innovative improvement in the form of a Police Service Information Management of Information System (Smile Police) which is an online integrated service based on Police-online. Smile Police consists of six applications, namely Panic Button, E-Office, Public Service, EBhabin, E-learning and E-Complaint. Public service improvement can be defined as a close correlation between actual perceptions and the desired standards of a public service (Boyne, 2010). There are three dimensions to be considered to improve the performance of public service organizations namely external environment, organizational characteristics, and strategies adopted by the organization. Then Bowman (2010) argued about the competence of professionalism of public services, especially technical competence, ethical competence, and leadership competence.

Unfortunately, the operation of Smile Police is not yet applied and accepted by society optimally. Borins (2001) and Drucker (1994) in a book written by Sabar, showed that the practice of governance innovation is difficult to implement in the public sector due to several factors, i.e. internal and external. Internal factors can inhibit innovation in the public sector, they are: a) The attitude of skepticism and reluctance to change; b) Dependency on the central budget; c) The mission of the public sector which is to ensure a fair allocation of resources, not to provide service according to the view of the market (citizen). The external factor is a factor derived from public service users. External factors which inhibit innovation in the public sector are caused by public doubt about the potency of a program.

The previous research which becomes references is, first, Research Journal by Nur Hidayati (2016) entitled "E-government dalam Pelayanan Publik Studi Kasus tentang faktor-faktor penghambat Inovasi Layanan E-Samsat Jatim Kabupaten Gresik". The results of the research show that the inhibiting factors of e-Samsat services from internal technology are not matched with the policies supporting innovation, people's desire for inappropriate services and external factors of society which is not ready to use e-Samsat due to hesitation of technology and society about the efficiency and effectiveness of e- 
Samsat services. Second is a research journals by Samekto Adi Nugroho (2017) entitled "Faktor-faktor penghambat pelayanan berbasis egovernment pada pembayaran pajak kendaraan bermotor dengan sistem anjungan transaksi mesin kantor bersama samsat di surabaya timur". The results of his research describe the operation of e-government vehicle tax program using ATM of Samsat East Java service and explaining factors which inhibit e-government-based services at ATM of Samsat Office in Samsat East Surabaya.

Based on the problems and previous research above, the focus of this article is to discuss about how Smile Police operation and the inhibiting factors of Smile Police operation. The results found that Smile Police has not been performed optimally because of the six Smile Police applications, there are only three applications used, especially Panic Button, E-Bhabin, and E-Office. There are still three other applications that have not been optimally used, namely, E-Public Service, E-learning and E-Complaint. The purpose of this research is to describe the operation of the Smile Police program in supporting to the realization of the Promoter Police (Professional, Modern and Trusted).

\section{Methods}

In this article, the method used here is documentation studies, literature obtained from international, national, and book journals. The steps taken are examining related to the utilization of information technology and public service communication at Central Java Regional Police.

The source used in the form of information and documents is related to aspects that is studied. Studied aspects are six Smile Police applications such as; E-Office Panic Button, E-Bhabin, E-Public Service, E-learning and E-Complaint. The research focus of this article is to describe the implementation of the Smile Police program in supporting the realization of the Promoter Police (Professional, Modern and Trusted).

Based on the data or information collected, it can be seen that from the six Smile Police applications, still there are applications that can't be used optimally i.e., E-Public Service, E-learning and E-Complaint. The obstacles are: 1) The working culture of the members of the Police changing from the manual system to the electronic system requires many adaptions; 2) Lack of socialization and training of POLRI to the community on how to use and access Smile Police and, 3) the majority of people is still at the level to not to care yet.

\section{Literature review}

Definition of Optimization

Definition of optimization according to Poerwadarminta (Ali, 2014) is the result achieved in accordance with the wishes, then optimization is the achievement of results in agreement with expectations of "effective and efficient". Optimization is also interpreted as a measure which all needs can be fulfilled from the activities performed. According to Winardi (Ali, 2014), optimization is a measure which is leading to the achievement of goals whenever it is viewed from the point of business. Optimization is the effort to maximize the activity until it understands the desired advantage. From the 
description, it is known that the optimization can only be accomplished if the manifestation is effective and efficient. In the management of the organization, regularly the aim is to achieve the results effectively and efficiently to be ideal.

\section{The Concept of Efficiency and Effectiveness}

Chester Barnard, cited in the Employee Performance Policy by Prawirosentono, (1999, p.28), the notion of effective and efficient is associated with a system of cooperation i.e. in corporate or government organizations. Efficiency, effectiveness and transparency are vital elements in implementing e-Government, until e-Government is in line with the effort to create good governance. In addition, e-Government is expected to support governance, productivity and efficiency in government agencies in enhancing economic growth. Thus, to face this global era, the Local Government is required to build commitment in all fields.

\section{Diffusion of Innovation Theory}

Diffusion of Innovation is the theory of how a new idea and technology spread in a culture. This theory was popularized by Everett Rogers in 1964 through his book 'Diffusion of Innovations'. It defines diffusion as the process by which an innovation is communicated through various channels and time periods within a social system.

The Diffusion of Innovation theory basically describes the process by which an innovation is communicated through certain channels over time to a group of members of the social system. This is in line with the diffusion notion of Rogers (1961), namely "as the process by which an innovation is communicated through certain channels over time among the members of a social system." Further explained, diffusion is a form of communication that is peculiarly related with the dissemination of messages in the form of new ideas, or in terms of Rogers (1961), diffusion concerns with "the source of the invention or creation of ultimate users or adopters."

\section{Definition of Information Communication Technologies}

Information and communication technology or ICT more popularly known as ICT term. The ICT stands for Information and Communication Technologies. In terms of the usage of ICT, it uses a combination of hardware and software. ICT is not a new thing in the world of Police. A common example is the use of information technology for SIM (driving license) production. Examples of implementation of information technology include the use of computers, digital cameras, fingerprint recorders, and SIM card printers. With the application of this technology, it is expected to create the SIM service completed more quickly. Related to that, Lucas (Munir, 2008: 41) argues that information technology is any form of technology applied to process and to send information in electronic form, microcomputer, mainframe computer, and barcode reader, transaction processing software, communication and network equipment that are examples of information technology. It provides information directly with the main help of computers and other technological tools. Therefore, in processing information, technology requires 
equipment and media to support the creation of communication through services helping the existence of transactions directly. The most important thing in the use of information and communication technology is the availability of components to support each other, such as software, hardware, process, and system for the purpose of delivering messages easily and being received quickly.

\section{Concept of Electronic Information Management Information System (Smile Police)}

Smile Police is a form of improvement of police services to the public using online system in Central Java region. Smile Police application is more referring to other definitions of e-Government. According to the Ministry of Communications and Informatics (Hardiansyah, 2003), e-Government is an application of Internet-based information technology and other digital devices managed by the government for the purpose of delivering information from the government to the public, business partners, employees, business entities and other institutions on line. There are a number of services in Smile Police needed by the community, they are:

a. Panic Button, is an Android-based application. When the user / community presses the panic button, this application will automatically send alert and user coordinate points to Central Java Police Command Center then for further to be dispatched to the officer who is near to the location for assistance b. E-Bhabin or Bhabinkamtibmas Electronic (The builder of security and public order of Bhayangkara). It is a mobile application that can be used by the people of Central Java to report an incident in the form of text and photos of incidents to the Police.

c. E-Public Service, is an application to support the service of Central Java Regional Police to the public such as registration service of SIM, BPKP, STNK and Police Note Certificate (SKCK) through mobile application.

d. E-Complaint is a mobile application that can be used by the people of Central Java to provide complaints or feedback to the Police for the services received.

e. E-learning, a system or concept of education / training handles information technology in the learning process for the purpose of providing learning materials for the community and members of the Police. The public can get information about Polri recruitment and practice of SIM theory test. While members of the Police who want to follow the education can access the learning materials.

f. E-office, is an electronic mail application based on web and mobile applications that are designed to accommodate hierarchical structures within an organization. 
Picture 1.

Interface of application of Smile Police

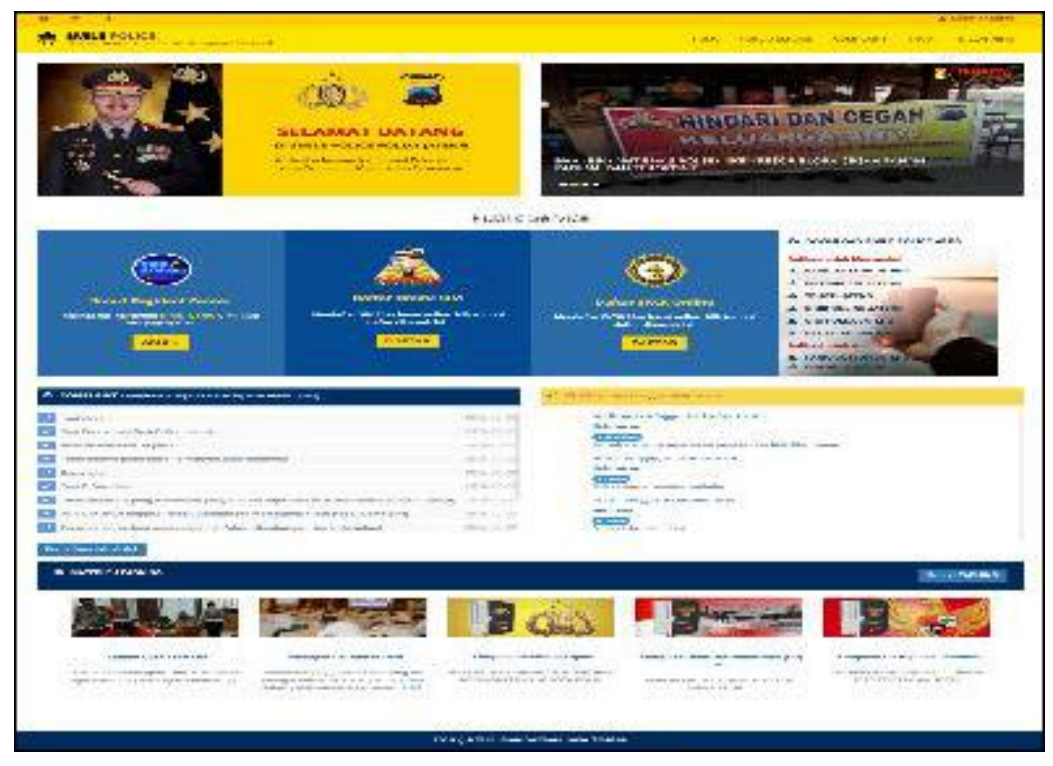

Smile Police is designed to integrate all information systems and applications used by Central Java Police into web-based interfaces according to the needs of Polda Central Java and some Mobile Apps. Smile Police can be accessed through the portal http://smilepolice.jateng.polri.go.id/.

Promoter (professional, modern, trusted)

Promoter stands for professional, modern, and trusted, is a flagship program of Police for purpose of improving public services and gaining public confidence in the Police. The descriptions of Promoter, they are:

a. Professional: Improving the competence of the increasingly qualified Police human resources through the development of education and training capacity, and conducting policing patterns based on standard procedures that have been understood, implemented, and measurable on its success.

b. Modern: Performing modernization in public services supported by technology making it easier and faster which can be accessed by the community. c. Trusted: Executing internal reforms towards a clean and free police service, in order to achieve an objective, transparent, accountable and equitable law enforcement.

The Promoter police is a Police who is capable of modernizing the mindset, culture set, strategy, instrumentation, and infrastructure possessed by putting forward the humanist approach while on duty, maintaining the attitudes and attributes, encouraging the values of morality, seeking to build its personal and institutional popularity by building partnerships and approaching the community sympathetically and empathetically, and committing to strengthen its integrity, and resulting in trustee community. 


\section{Results and discussion}

\section{Results}

Application of Smile Police

The results found that Smile Police is implemented by developing six applications, E-Office, Public Service, Panic Button, E-Bhabin, E-learning and EComplaint. These are six descriptions of applications used, they are:

Table 1.

Implementation of application of Smile Police

\begin{tabular}{|c|c|c|}
\hline Application & Content & Implementation \\
\hline E-Office & $\begin{array}{l}\text { The online administration } \\
\text { service application } \\
\text { provided to ease the } \\
\text { administration process }\end{array}$ & $\begin{array}{l}\text { Routine implemented, } \\
\text { currently still running }\end{array}$ \\
\hline E-Public Service & $\begin{array}{l}\text { An application to facilitate } \\
\text { various services in the field } \\
\text { of traffic and service } \\
\text { intelligence }\end{array}$ & $\begin{array}{l}\text { Not yet visible of the } \\
\text { implementation }\end{array}$ \\
\hline Panic Button & $\begin{array}{l}\text { Emergency message } \\
\text { delivery application, a kind } \\
\text { of request for asking a help } \\
\text { to police and relatives }\end{array}$ & $\begin{array}{l}\text { Routine implemented, } \\
\text { currently still running }\end{array}$ \\
\hline E-Bhabin & $\begin{array}{l}\text { Application with 'one shot } \\
\text { one report' concept }\end{array}$ & $\begin{array}{l}\text { Still used by members of } \\
\text { the police }\end{array}$ \\
\hline E-Learning & $\begin{array}{l}\text { Learning application for } \\
\text { polri and community } \\
\text { members }\end{array}$ & $\begin{array}{l}\text { Accessed by rarely police } \\
\text { and community members }\end{array}$ \\
\hline E-complaint & $\begin{array}{l}\text { An application of public } \\
\text { complaints services to } \\
\text { Police performance and } \\
\text { services }\end{array}$ & Not used \\
\hline
\end{tabular}

Based on table 1. it can be seen that the use of the Smile Police application as a total used is not yet optimal. From the six applications which are available in Smile Police, there are only three new applications routinely used, namely E-Office, Panic Button and E-Bhabin while for the other three applications; E-Public Service, E-learning and EComplaint have not been used, in the view of the utilization of the three applications, they are directly related to the service to the community. 
To see more clearly of the implementation of Smile Police application, the researchers present the data graphs of the applications usage that have been running.

Picture 2.

Application used of panic button

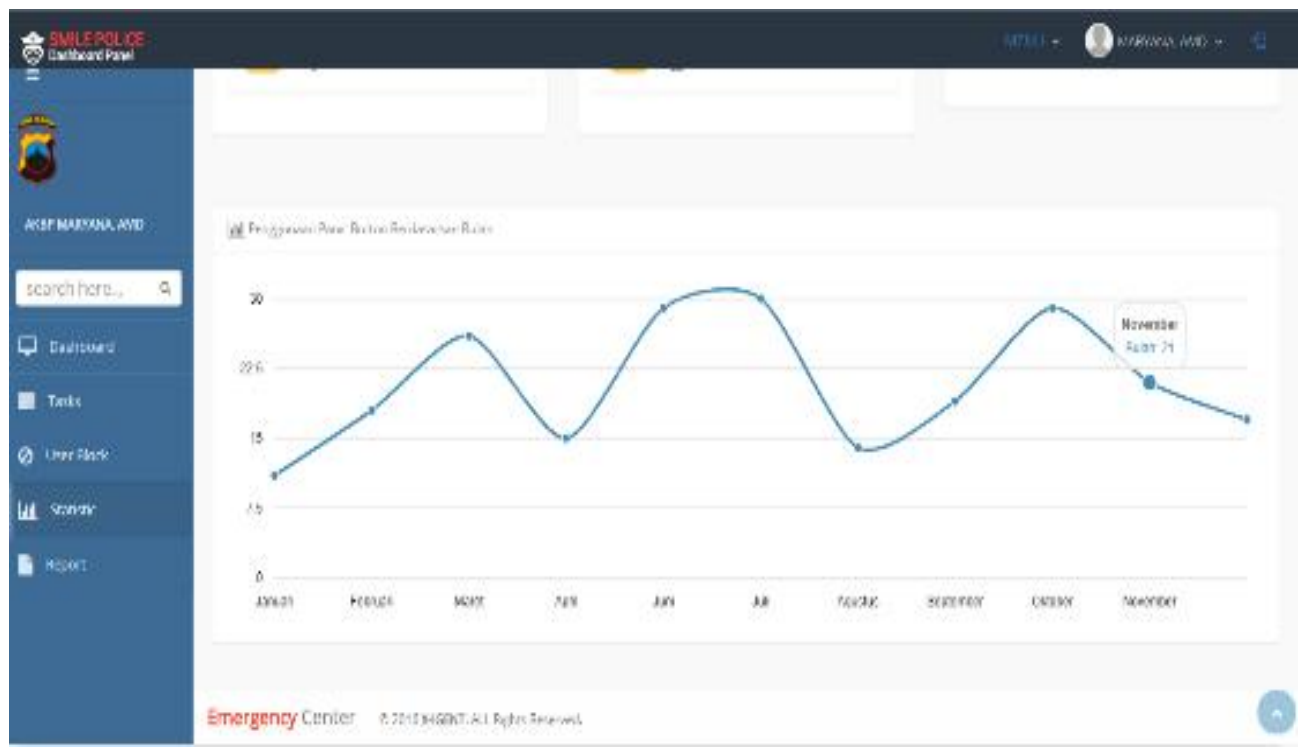

(Source: smilepolice.jateng.polri.go.id, accessed on 12 February 2018)

From picture 2. from the above, we can see the use of panic button from January to December 2017 that the public have accessed about 10-30 reports each month on average. The above data is an incident report from the community that has been handled by the police. To handle the time of incident, it takes the police approximately 15 minutes going from the nearest police to the state of urgency whether it will be criminal or other actions. People only need to push the button three times to run this feature. The success of the use of panic buttons will be seen if the higher the people use, the higher the level of crime or crime incident also, and the lower the people use, the lower the criminality level existed in the Central Java Police area. 


\section{Picture 3.}

\section{The Usage of Application of E-Bhabin}

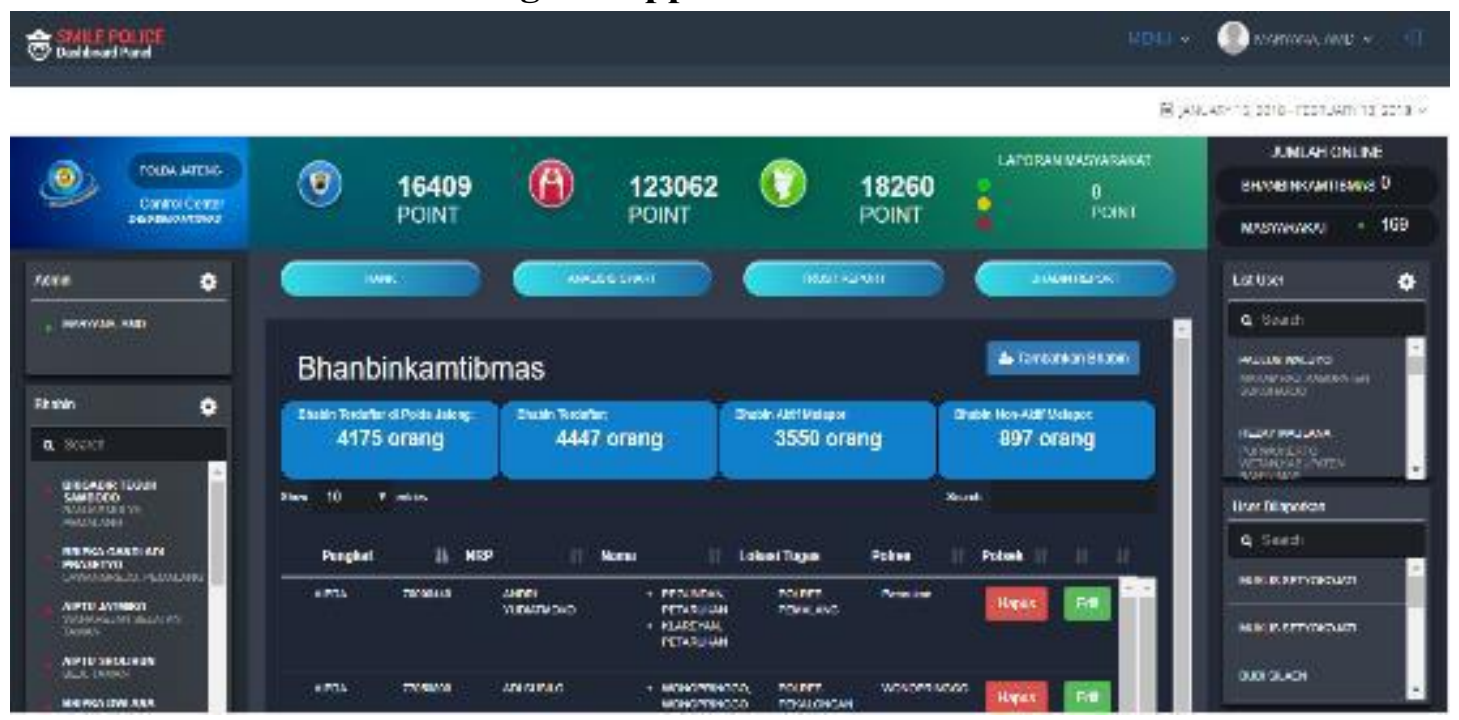

(Source: smilepolice.jateng.polri.go.id, accessed on 12 February 2018)

Picture 3 shows the number of Police (Bhayangkara instructor) members in the Central Java Police area who have downloaded and used the E-Babhin application. Of 4,447 Bhayangkara Instructor members, there are 4,175 registered in E-Bhabin number, actively reported by 3,550 and non-active reporting by 897 people.

Obstacles in the implementation of Smile Police

In implementing Smile Police application, it is not simple. There are several obstacles in the implementation of Smile Police both from the internal aspects of the police as well as the external aspects of society.

Table 2.

Obstacles in the implementation of Smile Police

\begin{tabular}{|l|l|l|}
\hline \multicolumn{1}{|c|}{ Obstacles } & \multicolumn{1}{|c|}{ Research findings } \\
$\begin{array}{l}\text { Changing the work culture } \\
\text { from manual system to } \\
\text { electronic system }\end{array}$ & $\begin{array}{l}\text { There are still many police } \\
\text { officers who have not been } \\
\text { literate on technology }\end{array}$ & $\begin{array}{l}\text { Indication } \\
\text { manual system }\end{array}$ \\
\hline $\begin{array}{l}\text { Lack of socialization of } \\
\text { Polri to society }\end{array}$ & $\begin{array}{l}\text { Socialization is often } \\
\text { executed but not being } \\
\text { followed by the training of } \\
\text { the procedure to use the } \\
\text { application }\end{array}$ & $\begin{array}{l}\text { Less of the utilization of } \\
\text { applications by the } \\
\text { community }\end{array}$ \\
\hline
\end{tabular}




\begin{tabular}{|l|l|l|}
\hline $\begin{array}{l}\text { Availability of android } \\
\text { smartphones }\end{array}$ & $\begin{array}{l}\text { Unavailability of android } \\
\text { smartphone for police } \\
\text { members }\end{array}$ & $\begin{array}{l}\text { Smartphone usage still } \\
\text { belongs to individuals }\end{array}$ \\
\hline $\begin{array}{l}\text { Understanding of } \\
\text { information technology }\end{array}$ & $\begin{array}{l}\text { The limitation of Polri's } \\
\text { human resources in } \\
\text { understanding the } \\
\text { information technology }\end{array}$ & $\begin{array}{l}\text { Difficult to learn with the } \\
\text { already static condition }\end{array}$ \\
\hline E-literacy of society & E-literacy of society & $\begin{array}{l}\text { The low level of } \\
\text { awareness of the use of } \\
\text { ICT communities }\end{array}$ \\
\hline
\end{tabular}

\section{Discussion}

Implementation of e-government should take into consideration to some of the conditions of priority of electronic services provided such as the condition of the infrastructure owned, the condition of the current service activities, and the condition of the budget and human resources owned. To that end, in the development of e-government, it is proposed by a form of organization through e-government development activities (Bastian, 2003).

Considering to the implementation of Smile Police application during the last one year, the implementation itself has not been optimally perceived by both the Police and the public. Judging from the comparison to the six existing applications in Smile Police, the most frequently accessed and used applications are E-office, E-Panic Button and EBhabin. Why are these three applications more frequently accessible?, because they are; a) E-office application relating to office administration activities is the process of distributing correspondence, disposition of leadership to subordinates and every three months evaluated from the use of the application, the results of the evaluation directly reported to the leadership, if there is less of utilization, they will be given a warning, $b$ ) The use of E-Panic Button and E-Bhabin applications is monitored in the Command Center, if there is any member of the police doesn't access the monitor, then it will be seen and required to provide a report on the results of the implementation of the activity.

The main objection faced is the lack of willingness, ability, and knowledge to change (from those who are not interested in technology, to being the technology literate). Therefore, a precise strategy is needed that can bring people to full awareness (or if it is necessary with forces) to use information and communication technology as an effective and efficient meaning to acquire the information they need. The most important thing here is the providers or creators of technology products related to the Police. The more difficult a technology is used or perceived by users, the harder it is to force people to use it. In view of this fact, the strategy that needs to be created is by doing activities such as: a) creating appropriate, user-friendly technology, b) teaching others about the fun and easiness of using technology, c) providing training services on how to use technology on communities, practicing quick and precise of information tips, unlocking the secrets of technological efficacy, etc. (Coovert, 1980). 


\section{Conclusion}

Based on the analysis that has been performed by the researchers, it can be concluded that Smile Police has not been implemented optimally, of the six applications contained in the new Smile Police application, there are only three applications that have been used optimally. In fact, if the application of Smile Police implemented optimally, then it will provide convenience to the public in obtaining services of police, so that the level of public confidence will increase and the Police Promoter (Professional, Modern and Terpercaya) will be accomplished.

The factors that inhibit the ineffectiveness of Smile Police Implementation, among others, they are:

a. The working culture of Police members from the manual system to the electronic system requires many of adjustments,

b. Lack of socialization and training of polri to the public about how to use and access Smile Police,

c. The unavailability of Android smartphones used to access Smile Police applications, especially for members of the Police and the public who are not ready to accept changes in the field of technology.

d. Limitations on the number and extent of the polri's human resources ability to understand information technology.

e. E-literacy of society as the main prerequisite to realize the knowledge based society, in general, most people are still at the level of ignorance (not yet understand) and few who have been at the level of lifestyle, they cannot be isolated with ICT.

\section{References}

Akadun. (2009). Teknologi Informasi Administrasi, Bandung: Alfabeta

Anthopulos L. (2015) Why e-government projects fail? An analysis of the Healthcare.gov website. Government Information Quarterly.

Bowman, James. S. (2010). Achieving Competencies in Public Services. The

Profesional Edge, Armonk NY: M.E. Sharpe.

Boyne, G., Asworth R., and Tom E. (2010). Public Service Improvement: Theories and Evidence. New York: Oxford University Press.

Hardiansyah. (2011). Kualitas Pelayanan Publik Konsep, Dimensi, dan Implementasinya. Yogyakarta: Gava Media

Hidayat, E.D. (2016). Peningkatan layanan publik melalui smart governance dan smart mobility. FISIP Universitas Terbuka, Pondok Cabe Pamulang, Tangerang Selatan, Banten, Jurnal Administrasi Pembangunan, Volume 4, No 2, Maret 2016, page 87156. 
Hidayati, N. (2016). E-government dalam pelayanan publik (Studi Kasus tentang Faktor-faktor Penghambat Inovasi Layanan E-Samsat Jatim di Kabupaten Gresik). Mahasiswa Program Studi Ilmu Administrasi Negara, FISIP, Universitas Airlangga, Kebijakan dan Manajemen Publik Volume 4, Nomor 3.

Indrajit, Richardus Eko. (2004). Electronics Government: strategi pembangunan dan pengembangan sistem pelayanan publik berbasis teknologi digital, Yogyakarta: Andi Yogyakarta.

Muhtadi, Ali. (2006). Pemanfaatan teknologi informasi untuk meningkatkan kualitas dan efektifitas pendidikan. Dinamika pendidikan. No.2/Th XIII.

Munir. (2008). Kurikulum Berbasis Teknologi Informasi dan Komunikasi. Bandung:Alfabeta

Nugroho, S. A. (2017). Faktor-faktor penghambat pelayanan berbasis egovernment pada pembayaran pajak kendaraan bermotor dengan sistem anjungan transaksi mesin kantor bersama samsat di surabaya timur. Mahasiswa Program Studi Ilmu Administrasi Negara, FISIP, Universitas Airlangga, Kebijakan dan Manajemen Publik Volume 5, Nomor 2, Mei - Agustus 2017.

Prasojo, E., Teguh K., dan Defny Holidin. (2007). Reformasi dan Inovasi Birokrasi. Jakarta:Yappika.

Sumantri, Agus. (2017). Tingkat Kepercayaan Publik Terhadap Polri Masih di Bawah TNI dan KPK. Accessed from:

http://news.metrotvnews.com/read/2017/12/29/808887/tingkat-kepercayaan-publikterhadap-polri-masih-di-bawah-tni-dan-kpk. Accessed on 11 January 2018.

Sufianti, Ely. (2007). Aplikasi E-Government Dalam Meningkatkan kualitas Pelayanan Publik Pada Pemerintah Daerah Kota/Kabupaten Di Indonesia. Jurnal Ilmu Administrasi Vol IV.

Wibawa, Samodra. (2012). Mengelola Negara, Gaya Media: Yogyakarta.

Widodo, Tri. (2014).Hambatan Inovasidan Strategi Pengembangannya. Accessed from: http://inovasi.lan.go.id/index.php?r=post/read\&id=38. Accessed on 14 January 2018.

Constitution No. 2 of year 2002 of Kepolisian Negara Republik Indonesia

Yanuarsasi Diati Putri, Heru Ribawanto, Stefanus Pani Rengu (2014). "Revitalisasi Polri Menuju Pelayanan Prima (Studi Pada Polres Tulungagung)": Malang, Jurusan Administrasi Publik, Fakultas Ilmu Administrasi, Universitas Brawijaya, Jurnal Administrasi Publik (JAP), Vol. 2, No 1, Page. 182-1 